\title{
Między ochroną a efektywnością. Systemowe i terminologiczne aspekty objęcia cywilnoprawnych umów o zatrudnienie ustawodawstwem pracy
} Between protection and effectivity. Covering civil law employment contracts with labour regulation - introductory remarks

prof. dr hab. Matgorzata Gersdorf

Uniwersytet Warszawski, Wydział Prawa i Administracji, Katedra Prawa Pracy i Polityki Społecznej m.gersdorf@wpia.uw.edu.pl

\begin{abstract}
Streszczenie Artykuł zawiera uwagi systemowe i ma charakter wprowadzenia do publikowanego w niniejszym numerze „Pracy i Zabezpieczenia Społecznego” zbioru artykułów ukazujących problematykę oddziaływania ustawodawstwa pracy na zatrudnienie niepracownicze, nawiązywane na podstawie umów prawa cywilnego. Zbiór prezentuje odmienności i podobieństwa w spojrzeniu na tę materię, jako wynik zespołowej pracy i indywidualnych analiz przygotowanych przez pracowników i współpracowników Katedry Prawa Pracy i Polityki Społecznej Wydziału Prawa i Administracji Uniwersytetu Warszawskiego. Ma stanowić syntezę dotychczasowych poglądów na tę materię, ewolucji stanu prawnego i dorobku judykatury, wskazując jednocześnie możliwe kierunki dalszego ich rozwoju.
\end{abstract}

Słowa kluczowe: zatrudnienie niepracownicze, Konstytucja RP, ochrona pracy.

Summary Hereby presented analyses focus on various ways labour legislation affects non labour (civil law based) employment. As a result of collective cooperation and individual activity of employees of the Department of Labour Law and Social Policy, Faculty of Law and Administration, University of Warsaw, they underline differences and similarities of views on the matter. Trying to gather understanding of the topic as presented so far with evolution of the legislation and judiciary, possible directions of solving future challenges are also available.

Keywords: non labour employment, Constitution of the Republic of Poland, protection of labour.

JEL: K31

Str. $2-5$

\section{Bibliografia}

Gersdorf, M. (1993). Umowa o pracę, umowa o dzieło, umowa zlecenia. Warszawa.

Gersdorf, M. (2013). Prawo zatrudnienia. Warszawa.

Grzybowski, S. M. (1947). Wstęp do nauki prawa pracy. Kraków.

Hajn, Z. (2000). Regulacja prawna zatrudnienia agentów. W: Z. Kubot (red.), Szczególne formy zatrudnienia. Wrocław.

Jończyk, J. (2000). O szczególnych formach zatrudnienia i formach ubezpieczeń społecznych. W: Z. Kubot (red.), Szczególneformy zatrudnienia. Wrocław.

Sobczyk, A. (2013). Prawo pracy w świetle Konstytucji. Warszawa. 